\title{
FAKTOR-FAKTOR YANG MEMPENGARUHI SELF EFFICACY PASIEN PENYAKIT JANTUNG KORONER SETELAH PERCUTANEOUS CORONARY INTERVENTION
}

\author{
Qodri Alamsyah ${ }^{1}$, Wan Nishfa Dewi², Wasisto Utomo ${ }^{3}$ \\ ${ }^{1,2,3}$ Fakultas Keperawatan Universitas Riau Jalan Pattimura No 9 Gedung G Pekanbaru Riau \\ Kode Pos 28131 Indonesia \\ email alamsyahqodry@gmail.com
}

\begin{abstract}
Abstrak
Self efficacy adalah keyakinan seseorang terhadap kemampuannya demi mencapai tujuan yang diinginkannya. Self efficacy pada penyakit jantung koroner setelah Percutaneous Coronary Intervention memiliki tiga faktor yaitu faktor keluarga, sosial, dan fisik. Penelitian ini bertujuan untuk mengetahui pengaruh faktor keluarga, sosial dan fisik terhadap self efficacy pasien penyakit jantung koroner setelah Percutaneous Coronary Intervention. Penelitian ini menggunakan metode deskriptif korelasi dengan pendekatan cross sectional. Sampel penelitian sebanyak 40 responden yang diambil berdasarkan kriteria inklusi dengan menggunakan teknik purposive sampling. Penelitian ini menggunakan uji chi square untuk melihat pengaruh semua faktor terhadap self efficacy. Hasil uji korelasi antara aspek keluarga terhadap self efficacy didapatkan $\mathrm{p}$ value $(0,001)<$ alpha $(0,05)$, aspek sosial terhadap self efficacy didapatkan p vaelue $(0,007)<$ alpha $(0,05)$, dan aspek fisik terhadap self efficacy didapatkan $\mathrm{p}$ value $(0,007)<$ alpha $(0,05)$, dimana pada aspek keluarga, sosial dan aspek fisik memiliki pengaruh terhadap self efficacy. Berdasarkan hasil penelitian ini diharapkan kepada pasien penyakit koroner setelah Percutaneous Coronary Intervention melibatkan keluarga, sosial serta fisik yang baik untuk meningkatkan self efficacy dalam meningkatkan kualitas hidup.
\end{abstract}

Kata Kunci : Aspek keluarga, Aspek fisik, Aspek sosial, Self eficacy, Penyakit jantung koroner, Percutaneous Coronary Intervention.

\begin{abstract}
Self efficacy is person's belief related to ability to achieve desired goals. Self efficacy patient with coronary heart disease after Percutaneous Coronary Intervention has three factors, namely family, social, and physical factors. This study aims to determine the effect of family, social and physical factors toward self efficacy patient with coronary heart disease after Percutaneous Coronary Intervention. This study used descriptive correlation desain with cross sectional approach. The sample of this study was 40 patients taken based on inclusion criteria using purposive sampling technique. The results of the correlation test between family aspects of self efficacy obtained $p$ value (0.001) <alpha (0.05), the social aspects of self efficacy obtained $p$ value (0.007) <alpha (0.05), and physical aspects of self efficacy obtained p value $(0,007)<$ alpha $(0,05)$. Based on the results of this study it is expected that patients with coronary disease after Percutaneous Coronary Intervention will have sufficient self efficacy when factors affecting self efficacy all good.
\end{abstract}

Keywords: Coronary heart disease, Family aspects, Percutaneous Coronary Intervention, Physical aspects, Self-efficacy, Social aspects.

\section{PENDAHULUAN}

Penyakit kardiovaskuler merupakan penyakit yang disebabkan oleh gangguan jantung dan pembuluh darah seperti penyakit gagal jantung, hipertensi, stroke, dan penyakit jantung koroner (PJK) (Kemenkes RI, 2013). Dapat dijelaskan bahwa penyakit kardiovaskuler merupakan salah satu penyebab utama kematian di seluruh dunia. Pada tahun 2015 sekitar 17,7 juta orang meninggal disebabkan penyakit kardiovaskuler atau sekitar $31 \%$ dari seluruh kematian di dunia (WHO, 2017).

Menurut hasil Riset Kesehatan Dasar 
pada tahun 2013 penyakit kardiovaskuler tertinggi yang pertama ialah stroke, yang kedua ialah penyakit jantung koroner dengan prevalensi $1,5 \%$. Data yang di dapatkan dari Kemenkes pada tahun 2013, prevalensi penyakit jantung koroner mengalami peningkatan pada usia 65-74 tahun yaitu sebesar 3,6\% dan mengalami penurunan pada usia 75 tahun keatas yaitu sebesar 3,2\% (Kemenkes, 2013). Hal ini bisa menyebabkan infark miokard serta kematian mendadak yang tinggi akibat dampak dari penyakit jantung koroner (Price \& Wilson, 2012).

Penyakit jantung koroner diakibatkan oleh plak yang menumpuk di arteri koroner (arterosklerosis). Plak tersebut dapat mengakibatkan penyempitan atau penyumbatan arteri koroner yang mengurangi aliran darah ke miokardium (Smeltzer et al dalam Wantiyah, 2010). Penyumbatan arteri koroner yang menyebabkan penurunan aliran darah ke miokardium dapat mengakibatkan gangguan pemasukan oksigen dan nutrisi ke dalam jaringan miokardium. Miokardium yang mengalami infark akan berhenti secara permanaen. Penatalaksanaan dalam memperbaiki daerah iskemia serta aliran darah ke miokardium agar tercapai dapat melakukan dilatasi arteria koronaria tanpa operasi yaitu Percutaneous Coronary Intervention (PCI) (Price \& Wilson, 2012).

Penelitian yang dilakukan Hutagalung, Mardiah, dan Susilaningsih (2014) tentang "Kualitas hidup pasien pasca intervensi koroner perkutan", mengatakan bahwa PCI memiliki tujuan untuk meningkatkan harapan hidup serta kualitas hidup pasien. Dalam meningkatkan harapan hidup serta kualitas hidup dapat dipengaruhi oleh persepsi individu yang berhubungan dengan tujuan hidup, harapan, dan standar yang menjadi keyakinan individu (self efficacy) itu sendiri.

Penelitian yang dilakukan oleh Sullivan et al (1998) melihat secara prospektif peran self efficacy tertentu dalam fungsi fisiknya serta peran pasien dalam penyakit jantung koroner dalam mengendalikan efek dari kecemasan dan depresi. Dalam model regrasi berganda, skala self efficacy secara signifikan memprediksi fungsi fisik, fungsi sosial, dan fungsi keluarga setelah mengendalikan kecemasan dan gejala depresi. Penelitian tersebut juga menjelaskan bahwa fungsi fisik dan fungsi sosial lebih relevan terhadap mempertahankan fungsi dalam self efficacy. Sedangkan peran keluarga sangat penting dalam meningkatkan self efficacy dalam mengontrol gejala. Berdasarkan studi pendahuluan yang dilakukan pada 11-12 April 2019 di ruang Poli Jantung RSUD Arifin Achmad didapatkan bahwa ada 11 orang pasien penyakit jantung koroner yang sudah terpasang PCI. Mereka juga mengatakan, bahwa mereka sangat membutuhkan motivasi dari keluarga dan lingkungan mereka dalam meningkatkan kesehatan serta mempertahankan fungsi. Berdasarkan fenomena tersebut peneliti tertarik untuk 
Jurnal Ners Indonesia, Vol.11 No.1, September 2020

melakukan suatu penelitian dalam mengidentifikasi factor-faktor yang mempengaruhi self efficacy pasien penyakit jantung koroner setelah PCI.

\section{METODE PENELITIAN}

Penelitian ini merupakan penelitian kuantitatif yang menggunakan metode deskriptif korelasi dengan pendekatan cross sectional. Lokasi penelitian ini di ruang Poli Jantung RSUD Arifin Achmad Pekanbaru dengan jumlah sampel 40 responden. Teknik pengambilan sampel menggunakan Teknik purposive sampling. Etika dalam penelitian yang dilakukan pada bulan Mei-Juni 2019 adalah lembar persetujuan responden, anonimity (Tanpa Nama), confidentiality (Kerahasiaan), beneficience (Kebaikan), justice (Keadilan), dan telah disetujui oleh pihak Unit Etik Penelitian Kedokteran dan Kesehatan dengan nomor uji etik 092/UN. 19.5.1.1.8/UEPKK/2019. Instrumen penelitian adalah kuesioner yang terdiri dari data demografi, aspek keluarga, aspek, fisik, aspek sosial, dan self efficacy. Analisis data yang digunakan adalah analisis univariat dan bivariat. Analisis bivariat digunakan untuk mengetahui adanya pengaruh yang signifikan antara variabel independen dan dependen.

\section{HASIL PENELITIAN}

Tabel 1

Distribusi karakteristik responden

\begin{tabular}{|c|c|c|}
\hline Karakteristik & Jumlah (n) & Persentase $(\%)$ \\
\hline \multicolumn{3}{|l|}{ Umur } \\
\hline Lansia Awal (46-55) & 11 & 27,5 \\
\hline Lansia (56-65) & 20 & 50 \\
\hline Manula (>65 tahun) & 9 & 22,5 \\
\hline \multicolumn{3}{|l|}{ Jenis Kelamin } \\
\hline Laki-laki & 36 & 90 \\
\hline Perempuan & 4 & 10 \\
\hline \multicolumn{3}{|l|}{ Pendidikan } \\
\hline Terakhir & & 2,5 \\
\hline Tidak Sekolah & 1 & \\
\hline SD & 1 & 2,5 \\
\hline SMP & 1 & 2,5 \\
\hline SMA & 24 & 60 \\
\hline Lainnya (PT) & 13 & 32,5 \\
\hline \multicolumn{3}{|l|}{ Status perkawinan } \\
\hline Menikah & 39 & 97,5 \\
\hline Duda/Janda & 1 & 2,5 \\
\hline \multicolumn{3}{|l|}{ Pekerjaan } \\
\hline Bekerja & 10 & 25 \\
\hline Tidak Bekerja & 30 & 75 \\
\hline \multicolumn{3}{|l|}{ Terakhir PCI } \\
\hline 4-6 Bulan yang lalu & 11 & 27,5 \\
\hline 7-12 Bulan yang lalu & 29 & 72,5 \\
\hline \multicolumn{3}{|l|}{ Banyak Sumbatan } \\
\hline 1 Sumbatan & 27 & 67,5 \\
\hline 2 Sumbatan & 11 & 27,5 \\
\hline 3 Sumbatan & 2 & 5,0 \\
\hline \multicolumn{3}{|l|}{ Tinggal Bersama } \\
\hline Suami & 4 & 10 \\
\hline Istri & 32 & 80 \\
\hline Anak & 4 & 10 \\
\hline Total & 40 & 100 \\
\hline
\end{tabular}

sebagian besar responden adalah umur lansia (56-65) tahun, yaitu sebanyak 20 orang (50\%), sebagian besar responden berjenis kelamin laki-laki yaitu sekitar 36 orang (90\%), sebagian besar memiliki pendidikan SMA yaitu sekitar 24 orang (60\%), sebagian besar responden memiliki status perkawinan kawin yaitu sebanyak 39 orang $(97,5 \%)$, sebagian besar responden adalah tidak bekerja yaitu sebesar 30 orang (75\%). Sebagian besar responden melakukan pemasangan PCI pada 1 tahun terakhir yaitu sebanyak 29 orang (72,5\%), sebagian besar responden hanya 
Qodri Alamsyah, Wan Nishfa Dewi, dan Wasisto Utomo, Faktor-Faktor yang Mempengaruhi Self Efficacy Pasien Penyakit Jantung Koroner Setelah Percutaneous Coronary Intervention

memiliki 1 sumbatan yaitu sebanyak 27 orang $(67,5 \%)$, dan mayoritas tinggal bersama keluarga (Istri/Suami) yaitu sebanyak 36 orang $(90 \%)$.

\section{B. Analisa Bivariat}

1. Pengaruh Aspek Keluarga Terhadap Self Efficacy Pasien Penyakit Jantung Koroner Setelah PCI.

Tabel 2

Pengaruh aspek keluarga terhadap self efficacy pasien penyakit jantung koroner setelah PCI.

\begin{tabular}{|c|c|c|c|c|}
\hline \multirow[t]{3}{*}{ variabel } & \multicolumn{2}{|c|}{ Self Efficacy } & \multirow[t]{2}{*}{ Total } & \multirow{2}{*}{$\begin{array}{l}\mathrm{P} \\
\text { Value }\end{array}$} \\
\hline & Baik & $\begin{array}{l}\text { Kurang } \\
\text { Baik }\end{array}$ & & \\
\hline & & $\mathrm{n} \%$ & $\mathrm{n}$ & \\
\hline
\end{tabular}

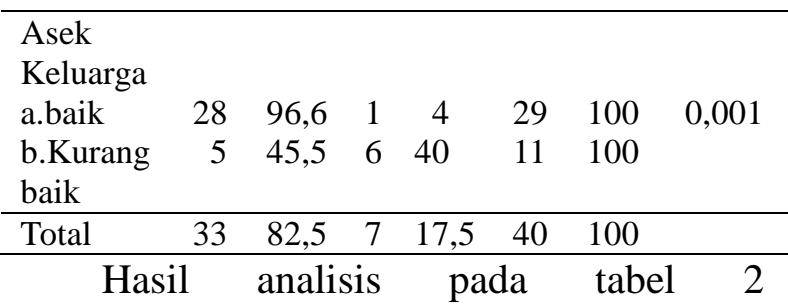

menunjukkan bahwa 29 responden yang memiliki aspek keluarga baik didapatkan sebagian besar responden memiliki self efficacy baik, yaitu sekitar 28 orang (96,6\%). Berdasarkan hasil uji Chi-Square didapatkan $\mathrm{p}$ value $0,001<0,05$ yang menunjukkan Ho ditolak, sehingga dapat disimpulkan bahwa ada pengaruh aspek keluarga terhadap self efficacy pasien penyakit jantung koroner setelah PCI.

\section{Pengaruh Aspek Sosial Terhadap}

\section{Self Efficacy Pasien Penyakit}

\section{Jantung Koroner Setelah PCI.}

Tabel 3

Pengaruh aspek sosial terhadap self efficacy pasien penyakit jantung koroner setelah PCI.

\begin{tabular}{|c|c|c|c|c|c|c|c|}
\hline \multirow[t]{3}{*}{ variabel } & \multicolumn{4}{|c|}{ Self Efficacy } & \multirow{2}{*}{\multicolumn{2}{|c|}{ Total }} & \multirow{3}{*}{$\begin{array}{l}\mathrm{P} \\
\text { Value }\end{array}$} \\
\hline & \multicolumn{2}{|c|}{ Baik } & \multicolumn{2}{|c|}{$\begin{array}{l}\text { Kurang } \\
\text { Baik }\end{array}$} & & & \\
\hline & $\mathrm{N}$ & $\%$ & $\mathrm{n}$ & $\%$ & $\mathrm{n}$ & $\%$ & \\
\hline $\begin{array}{l}\text { Asek } \\
\text { Sosial }\end{array}$ & 24 & & 1 & & 25 & & 0007 \\
\hline $\begin{array}{l}\text { b.Kurang } \\
\text { baik }\end{array}$ & 9 & 60 & $\begin{array}{l}1 \\
6\end{array}$ & $\begin{array}{r}4 \\
40\end{array}$ & 15 & 100 & \\
\hline Total & 33 & 82,5 & 7 & 17,5 & 40 & 100 & \\
\hline
\end{tabular}

Hasil analisis pada tabel 3 menunjukkan bahwa 25 responden yang memiliki aspek sosial baik didapatkan sebagian besar responden memiliki self efficacy baik, yaitu sekitar 24 orang (96\%). Berdasarkan hasil uji Chi-Square didapatkan $\mathrm{p}$ value $0,007<0,05$ maka hasil ini menunjukkan Ho ditolak, sehingga dapat disimpulkan bahwa ada pengaruh aspek sosial terhadap self efficacy pasien penyakit jantung koroner setelah PCI.

\section{Pengaruh Aspek Fisik Terhadap Self}

Efficacy Pasien Penyakit Jantung

\section{Koroner Setelah PCI.}

Tabel 4

Pengaruh aspek fisik terhadap self efficacy pasien penyakit jantung koroner setelah PCI.

\begin{tabular}{|c|c|c|c|c|}
\hline \multirow[t]{2}{*}{ variabel } & \multicolumn{2}{|c|}{ Self Efficacy } & \multirow[t]{2}{*}{ Total } & \multirow[t]{2}{*}{ P Value } \\
\hline & Baik & $\begin{array}{l}\text { Kurang } \\
\text { Baik }\end{array}$ & & \\
\hline
\end{tabular}

\begin{tabular}{lrrrrrrr}
\hline Asek & & & & & & & \\
Fisik & & & & & & & \\
a.baik & 24 & 96 & 1 & 4 & 25 & 100 & 0,007 \\
$\begin{array}{l}\text { b.Kuran } \\
\text { g baik }\end{array}$ & 9 & 60 & 6 & 40 & 15 & 100 & \\
\hline Total & 33 & 82,5 & 7 & 17,5 & 40 & 100 & \\
\hline
\end{tabular}


Hasil analisis pada tabel 4 menunjukkan hasil uji Chi-Square didapatkan $\mathrm{p}$ value $0,007<0,05$ maka hasil ini menunjukkan Ho ditolak, sehingga dapat disimpulkan bahwa ada pengaruh aspek fisik terhadap self efficacy pasien penyakit jantung koroner setelah PCI.

\section{PEMBAHASAN}

\section{A. Analisis Univariat}

\section{Karakteristik responden}

\section{A. Umur}

Hasil penelitian terhadap 40 responden di ruangan Poli Jantung RSUD Arifin Achmad menunjukkan bahwa sebagian besar responden adalah umur 56-65 tahun, yaitu sebanyak 20 orang (50\%). Penelitian ini menunjukkan bahwa jumlah responden sebagian besar adalah lansia memiliki self efficacy baik. Lansia yang memiliki self efficacy yang lebih baik akan mampu dalam mengontrol gejala-gejala yang dialami dalam mempertahankan fungsi kesehatan diri dari usia dewasa muda.

Umur yang semakin dewasa akan membuat individu berfokus pada self efficacy yang dimiliki untuk lebih mampu menyelesaikan masalah (Dwidiyanti, Margawati \& Noorrati, 2016). Lansia akan lebih memiliki tingkat kepercayaan terhadap kemampuannya dalam mengelola dan mengontrol penyakitnya menjadi lebih baik daripada usia dewasa muda (Brown dalam Dwidiyanti, Margawati, \& Noorrati, 2016).

Usia yang semakin dewasa akan membuat seseorang semakin memiliki tingkat self efficacy yang lebih baik sehingga seseorang akan lebih mampu dalam mempertahankan status kesehatannya serta mengontrol gejalagejala yang dimilikinya dalam mempertahankan fungsi kesehatannya.

\section{B. Jenis Kelamin}

Berdasarkan hasil penelitian didapatkan sebagian besar responden berjenis kelamin laki-laki yaitu sebanyak 36 orang (90\%). Hal ini sejalan penelitian yang dilakukan oleh Dewi (2018) yang mendapatkan jenis kelamin terbanyak adalah laki-laki yaitu 30 orang $(85,7 \%)$. Dalam penelitian ini didapatkan sebagian besar responden merupakan laki-laki yang memiliki self efficacy yang baik. Jenis kelamin laki-laki akan lebih cenderung memiliki keyakinan dan kemampuan lebih tinggi serta mampu mengatasi masalah sendiri.

Bandura (dalam Amelia, 2017) mengemukakan bahwa faktor yang mempengaruhi self efficacy adalah jenis kelamin. Laki-laki akan lebih cenderung memiliki self efficacy yang tinggi serta lebih mampu dalam mengatasi berbagai masalah secara mandiri (Wantiyah,2010). 
Qodri Alamsyah, Wan Nishfa Dewi, dan Wasisto Utomo, Faktor-Faktor yang Mempengaruhi Self Efficacy Pasien Penyakit Jantung Koroner Setelah Percutaneous Coronary Intervention

\section{Tingkat Pendidikan}

Berdasarkan penelitian yang telah dilakukan di ruangan Poli Jantung RSUD Aifin Achmad didapatkan hasil bahwa tingkat pendidikan terbanyak adalah SMA, yaitu sebanyak 24 orang $(60 \%)$, serta tingkat pendidikan terbanyak kedua adalah pendidikan lainnya yaitu sebanyak 13 orang $(32,5 \%)$. Hidayati dan Kusuma (2013) menyatakan individu yang memiliki pendidikan yang tinggi juga memiliki self efficacy yang baik. Pendidikan seseorang akan membentuk sikap dan perilaku seseorang tehadap lingkungannya (Notoatmodjo dalam Lutfa \& Maliya, 2008).

\section{Status perkawinan}

Berdasarkan penelitian yang telah dilakukan di ruangan Poli Jantung RSUD Arifin Achmad didapatkan hasil bahwa status perkawinan terbanyak adalah kawin yaitu sebanyak 39 orang $(97,5 \%)$. Status perkawinan menunjukkan bahwa pasangan hidup dapat membantu dan mendorong keyakinan individu sehingga dapat mempengaruhi self efficacy pasangannya (Al-Kahfi, Marlina \& Palimbo, 2016). Bandura (dalam Ayu, 2017) mengemukakan salah satu sumber self efficacy adalah verbal persuasion, yaitu kata-kata motivasi dan kritik yang diberikan dari orang yang berada di sekitar individu.

\section{E. Pekerjaan}

Pada penelitian yang telah dilakukan kepada 40 responden di ruang Poli Jantung RSUD Arifin Achmad menunjukkan bahwa sebagian besar responden adalah tidak bekerja, yaitu sebanyak 30 orang (75\%). Hal ini sejalan dngan penelitian yang dilakukan oleh Wantiyah (2010) mengemukakan bahwa karakteritik responden berdasarkan pekerjaan didapatkan sebagian besar tidak bekerja yaitu $74,8 \%$. Orang yang memiliki pekerjaan akan menjadi lebih bertanggung jawab dan tenang terhadap kesehatan dirinya. Seseorang yang memiliki self efficacy tinggi akan memiliki perilaku yang lebih sehat (Hamidah \& Herdianto, 2014). Akan tetapi karakteristik responden pekerjaan tidak berpengaruh secara signifikan terhadap self efficacy pasien penyakit jantung koroner (Lau-Walker, dalam Wantiyah, 2010).

\section{F. Jumlah Sumbatan}

Pada hasil penelitian yang telah dilakukan di RSUD Arifin Ahmad terhadap 40 responden didapatkan hasil bahwa responden lebih banyak memiliki 1 sumbatan, yaitu sebanyak 27 orang $(67,5)$. Kondisi fisik akan menimbulkan kondisi emosional pada kondisi tertentu (Feist, Feist, \& Roberts, 2017). Sehingga kondisi fisiologis dan emosional akan menjadi peningkat dari self efficacy seseorang. Jumlah sumbatan yang sedikit akan 
membuat kondisi fisik lebih baik akan membuat kondisi emosional lebih kuat dalam mepengaruhi individu dalam meningkatkan self efficacy. Jumlah yang semakin banyak akan membuat kondisi fisik pasien tidak baik dan dapat mempengaruhi kondisi emosional menjadi tidak baik.

\section{G. Waktu Terakhir Dilakukan PCI.}

Berdasarkan hasil penelitian yang telah dilakukan peneliti terhadap 40 responden di Ruang Poli Jantung RSUD Arifin Achmad menunjukkan bahwa sebagian besar responden adalah 1 tahun terakhir, yaitu sebanyak 29 orang $(72,9 \%)$. Pengalaman yang didapatkan seseorang dapat menjadi pengaruh terhadap self efficacy yang lebih kuat (Alwisol, 2009). Pencapaian keberhasilan yang pernah didapatkan dimasa lalu akan memberi dampak yang baik terhadap self efficacy.

\section{H. Tinggal Bersama siapa}

Berdasarkan hasil penelitian yang telah dilakukan peneliti terhadap 40 responden di Ruang Poli Jantung RSUD Arifin Achmad menunjukkan bahwa sebagian besar responden adalah tinggal bersama keluarga (Istri/Suami), yaitu sebanyak 36 orang (90\%). Dewi, Dewi, dan Herlina (2018) mengungkapkan bahwa motivasi dari pasangan sangat diperlukan untuk memberikan dukungan serta informasi dalam mengatasi masalah kesehatan sehingga individu dapat mempertahankan kesehatan dengan baik. Self efficacy akan meningkat apabila indvidu menerima motivasi dari orang terdekatnya salah satunya adalah pasangan hidup.

\section{B. Analisa Bivariat}

1. Pengaruh Aspek Keluarga, Sosial, dan Fisik terhadap self efficacy pasien penyakit jantung koroner setelah PCI.

Penelitian yang telah dilakukan terhadap 40 responden di ruangan Poli Jantung RSUD Arifin Achmad didapatkan bahwa hasil analisis pengaruh aspek keluarga terhadap self efficacy menunjukkan responden yang memiliki aspek keluarga baik terhadap self efficacy baik yaitu sekitar 28 orang $(96,6 \%)$. Hasil analisis dari penelitian yang telah dilakukan didapatkan hasil $\mathrm{p}$ value = $0,001<0,05$ yang menunjukkan Ho ditolak. Pada aspek sosial baik terhadap self efficacy baik yaitu sekitar 24 orang $(96 \%)$. Hasil analisis dari penelitian yang telah dilakukan didapatkan hasil $\mathrm{p}$ value $=$ $0,007<0,05$ yang menunjukkan Ho ditolak, sedangkan pada aspek fisik baik terhadap self efficacy baik yaitu sekitar 26 orang (96\%). Hasil analisis dari penelitian yang telah dilakukan didapatkan hasil $p$ value $=0,007<0,05$ yang menunjukkan Ho ditolak, sehingga dapat disimpulkan bahwa ada pengaruh aspek keluarga, sosial, fisik terhadap self efficacy pasien penyakit jantung koroner setelah PCI. 
Dari ketiga hasil tersebut bahwa aspek keluarga memiliki pengaruh yang sangat signifikan terhadap self efficacy. Hal ini sesuai dengan penelitian Wahyuni (2018) bahwa terdapat pengaruh aspek keluarga terhadap self efficacy yaitu sebesar $60 \%$ keluarga dapat memberikan bimbingan, nasihat terhadap seseorang. Dukungan keluarga sangat berperan penting dalam meningkatkan self efficacy pasien penyakit jantung koroner dalam mengontrol gejala dan mempertahankan fungsi fisik.

Karunia (2016) mengungkapkan bahwa keputusan, nasihat, serta saran yang dibuat anggota keluarga dapat mempengaruhi tingkat kemandirian seseorang dalam melakukan pengobatan. Tingkat kemandirian didapatkan akibat dari self efficacy yang baik, sehingga dengan self efficacy yang baik seseorang akan mengambil keputusan secara maksimal. Seseorang dapat diarahkan dengan nasihat, bimbingan, serta saran, dapat meningkatkan kemampuan yang dimilikinya sehingga dapat membantu seseorang dalam mencapai tujuan yang diingkannya (Bandura dalam Feist \& Feist, 2008). Berbeda hal dengan aspek sosial dan fisik yang dimana mereka mendapatkan hasil lebih rendah dari aspek keluarga. Hal ini disebabkan aspek sosial hanya melakukan observasi terhadap apa yang dilihat, tidak dengan kedekatan yang ia miliki serta pengalaman yang tidak terduga, dan juga hanya mendapatkan pengalaman dari orang lain

Seperti yang di jelaskan oleh Feist, Feist, dan Roberts mengungkan bahwa self efficacy dapat meningkat dengan pengalaman yang tidak terduga. Sedangkan pada aspek fisik yang memiliki hasil sama dengan aspek sosial dimana juga lebih rendah dari pada aspek keluarga. Dimana pada aspek fisik disini hanya memiliki fokus fisik yang lebih baik. Performa yang berhasil akan meningkatkan self efficacy secara proposional dengan kesulitan dari tugas (Feist, Feist, \& Robert, 2017).

\section{Keterbatasan Penelitian}

1. Populasi pasien yang ada dalam penelitian sedikit, sehingga peneliti cukup sulit dalam mendapatkan responden sesuai dengan kriteria yang ditetapkan oleh peneliti.

2. Peneliti menggunakan metode cross sectional dimana penelitian hanya dilakukan di satu titik, sehingga peneliti tidak dapat mengobservasi secara langsung bagaimana pengaruh aspek keluarga, sosial, dan fisik terhadap self efficacy responden. Untuk hasil yang lebih baik sebaiknya metode penelitian juga dilakukan dengan menggunakan observasi ke responden. 


\section{SIMPULAN}

Penelitian ini mengenai faktor-faktor yang mempengaruhi self efficacy pasien penyakit jantung koroner setelah PCI. yang dilakukan kepada 40 orang responden di ruangan Poli Jantung RSUD Arifin Achmad Pekanbaru. Faktor- faktor yang ada pada penelitian ini ada tiga yaitu, aspek keluarga, aspek fisik dan aspek sosial. Dimana dari ketiga faktor tersebut semuanya memiliki pengaruh terhadap self efficacy dengan hasil yaitu aspek keluarga mendapatkan hasil sekitar dengan p value $0.001<0.05$, pada aspek sosial didapatkan hasil sekitar dengan $\mathrm{p}$ value $0.007<0.05$, dan pada aspek fisik didapatkan hasil dengan $\mathrm{p}$ value $0.007<0.05$. hal ini menunjukkan bahwa keluarga, sosial, dan fisik, memiliki pengaruh terhadap self efficacy pasien penyakit jantung koroner setelah PCI. Dengan adanya self efficacy yang kuat dapat meningkatkan kualitas hidup individu itu sendiri.

\section{SARAN}

Bagi Pengembangan Ilmu Keperawatan

Tenaga Kesehatan diharapkan dapat meningkatkan pemahaman tentang faktor-faktor yang mempengaruhi self efficacy pada pasien penyakit jantung koroner setelah PCI dalam meningkatkan kesehatanya.

\section{DAFTAR PUSTAKA}

Al-Kahfi, R., Marlina \& Plimbo, A. (2016). Pengaruh efikasi diri dan dukungan keluarga terhadap pencegahan kaki diabetik pada pasien rawat jalan diabetes militus tipe 2 di RSUD Dr. J. Movh. Ansari Saleh Banjarmasin. Dinamika kesehatan. Diperoleh pada tanggal 1 Juni 2019 dari http//ojs.dinamikakesehatan.stikessarimu lia.ac.id/index.php.dksm/article/view/14 $6 / 120$.

Alwisol. (2009). Psikologi keperibadian. Malang: UMM Press.

Amalia. (2017). Hubungan self efficacy dengan perawatan diri lansia hipertensi. Jurnal keperawatan BSI. Diperoleh pada tanggal 1 juni 2019 dari https://ejournal.bsi.ac.id/ejurnal/index.ph p./jk/article/view/2631.

Ayu, D.S., Renanita, T. \& Setiawan, J.L. (2017). Hubungan antara dukungan orang tua dan dukungan pasangan dengan resilience of eicacy pada pramugari. Psychopreneur Journal. Diperoleh pada tangga 30 Mei 2019 dari https://journal.uc.ac.ic/index.php/psy/art icle/view/355.

Dewi, M. Y., Dewi. W. N., \& Herlina. (2018). Self efficacy pasien penyakit jantung koroner setelah percutaneous coronary intervention. Diperoleh tanggal 11 Februari $2018 \quad$ di https://jom.unri.ac.id/index.php/JOMPSI K/article/viewFile/23064/22329.

Dwidiyanti, M., Margawati, A., \& Noorratri, E.D. (2016). Faktor yang mempengaruhi efikasi diri pada pasien TB paru. Jurnal of nursing and health. Diperoleh pada tanggal $31 \quad$ Mei 2019 dari http://jurnal.akperyakpermas.ac.id/index .php/jnh/article/download/7/7.

Feist, G. J. \& Feist, J. \& Roberts, T.A. (2017). Teori kepribadian edisi 8 jilid 2. Jakarta: Salemba Humanika.

Feist, G. J. \& Feist, J. (2008). Theories of personality. Yogyakarta: Pustaka Pelajar.

Hamidah \& Herdianto, Y. (2014). Hubungan self-efficacy dengan perilaku sehat pada 
Qodri Alamsyah, Wan Nishfa Dewi, dan Wasisto Utomo, Faktor-Faktor yang Mempengaruhi Self Efficacy Pasien Penyakit Jantung Koroner Setelah Percutaneous Coronary Intervention

penderita jantung koroner. Jurnal Psikologi Klinis dam Kesehatan Mental. Diperoleh pada tanggal 27 Januari 2019 dari

http://journal.unair.ac.id/JPKK@hubung an-antara-self-efficacy-dengan-perilakusehat-pada-penderita-jantung-koroner-a rticle-8778-media-51-category-10.html.

Hutagalung, R.U., Mardiyah, A. \& Susilaningsih, S. (2014). Kualitas hidup pasien pascaintervensi koroner perkutan. Jurnal Keperawatan Padjadjaran. Diperoleh tanggal 30 Januari 2019 dari http://www.jkp.fkep.unpad.ac.id/index.ph p/jkp/articleview/192.

Hidayati, W. \& Kusuma, H. (2013). Hubungan antara motivasi dengan efikasi diri pada pasien diabetes militus tipe 2 di Persada Salatiga. Jurnal Medikal Bedah. Diperoleh tanggal 1 Juni 2019 dari https://jurnal.unimus.ac.id/index.php/jkp /article/view/77/73

Karunia, E. (2016). Hubungan antara dukungan keluarga dengan kemandirian activity of daily living pascastroke. Jurnal berkala epidemiologi vol 4 no 2 . Diperoleh tanggal 30 Mei 2019 dari https://e-journal.unair.ac.id/JBE/article/ viewFile/\%202147/2462

Kementrian Kesehatan. (2013). Riset kesehatan dasar. Jakarta: Balitbangkes Kementrian Kesehatan RI.

Lutfa, U., \& Maliya, A. (2008). Faktor- faktor yang mempengaruhi kecemasan pasien dalam tindakan kemoterapi di Rumah
Sakit DR. MOEWARDI Surakarta. Berita Ilmu Keperawatan. Vol 1 nomor 4. Diperoleh pada tanggal 19 Juni 2019 dari

http://journals.ums.ac.id/index.php/BIK/ article/download/3733/2403

Price, S.A. \& Wilson, L.M. (2012). Patofisiologi: Konsep klinis

Sullivan. (1998). Self efficacy and self-reported funtional status in coronary heart disease: A Six-Month Prospective Study. Diperoleh pada tanggal 30 Januari 2019 dari https://journals.lww.com/psychosomatic medicine/Abstract/1998/0700/Self_Effic acy_and_Self

_Reported_Functional_Status.14.aspx

Wahyuni, S., \& Dewi, C. (2018). Faktor-faktor yang berhubungan dengan efikasi pasien pasca stroke: studi cross sectional di RSUD Gambira Kediri. Jurnal Wiyata Vol 5 No 2. Diperoleh pada tanggal 1 Juni $2019 \quad$ dari file:///C:/Users/Qodry\%20Alamsyah\%20 Lubis/Downloads/214-587-1-PB\%20(1). $p d f$

Wantiyah. (2010). Analisis faktor-faktor yang mempengaruhi efikasi diri pasien penyakit jantung koroner dalam konteks asuhan keperawatan di RSD dr. Soebandi Jember. Doperoleh pada tanggal 3 Desember 2018 di http://lib.ui.ac.id/detail id $=137273 \&$ lok asi $=$ lokal. 